\title{
Evaluation of Blackgram Germplasm for Resistance against YMV
}

\author{
Peeta Gopi', Satyanarayana A², Rama Krishna A $^{2}$ and Sambasiva Rao KRS ${ }^{1 *}$
}

${ }^{1}$ Department of Biotechnology, Acharya Nagarjuna University, Guntur - 522510, AP, India

${ }^{2}$ NRI Agritech Pvt. Ltd, Vidyanagar, Guntur -522007, AP, India

\begin{abstract}
The experiment carried out at the R\&D Farm, NRI Agritech and ANU, Nagarjuna Nagar, Guntur. To identify genetic sources of resistance to yellow mosaic virus (YMV) in blackgram vigna mungo (L), 49 germplasm lines are collected from different geographical regions were evaluated under field conditions during period rabi season November 2014 - February 2015, 2 entries exhibited resistance(R) reaction with rating of 1.0 to 2.0. Six genotypes feel in the category of moderately resistant (MR) with rating scale of 2.1 to 4.0 , three were moderately susceptible (MS) with rating of 4.1 to 5.0; two genotypes were susceptible (S) with rating of 5.1 to 7 ; and 35 genotypes were highly susceptible (HS) with rating 7.1 to 9 . This study reveals new source of resistance for use breeding programme aimed at developing YMV resistant varieties.
\end{abstract}

Keywords: Blackgram (urdbean); Yellow mosaic virus; MYMV Resistance breeding

\section{Introduction}

Blackgram (minumulu) is a very important grain legume crop grown in Andhra Pradesh in all the seasons but predominantly during rabi under rice fallows. The Guntur District ranks first in Andhra Pradesh for the production of blackgram. Blackgram is very nutritious as it contains high levels of proteins, potassium, calcium, iron, niacin (B3), thimine ( $\mathrm{B}_{1}$ ), Riboflavin (B2) [1]. Blackgram has been shown to be useful in mitigating elevated cholesterol levels. Blackgram has received prominence in Indian dites especially for culinary preparation of dal, Idli, Vada, Dosa, papad (Table 1).

Although blackgram has been traditionally cultivated after rice in krishna delta, it was consider only as subsistent crop with yields usually below $0.5 \mathrm{t} / \mathrm{ha}$. Following comprehensive constraint analysis in 1980's cultivar improvement programme was initiated Satyanarayana 1994 and the resistant disease resistant varieties LBG-17 (powderynildw disease), LBG -402 (wilt), LBG - 645 banda polish (wilt) etc... With yields exceeding $2.5 \mathrm{t} /$ ha under with minimal management conditions. The above cultivars catalyzed commercialization of crop on large scale and economy of the farmers as well as sustainability of the production system. Blackgram production in rice fellows contributed to area and production increase in the state from $410 \mathrm{~kg} /$ ha on 21900 ha in 198182 to $737 \mathrm{~kg} / \mathrm{ha}$ on 560,000 ha in $1991-92$.

In period of 2012-14, YMV was found in black gram. Due to this reason production of black gram was gradually declined. The grain achieved through the location specific technology developed have diminished for past decade due to YMV disease problem on Black gram in this area resulting in lower returns, shift to exploitative crops and un sustainability of system. Due to YMV, effect black gram crop area is diverted to maize, sorghum, due to non-availability of resistant varieties. Yellow mosaic disease is the most destructive disease on black gram both in Kharif and Rabi seasons. YMV is most distractive

\begin{tabular}{|c|c|c|c|}
\hline Year & Area lakh/ha & Production lakh/t & Productivity ( kg/ha) \\
\hline $1981-82$ & 2.19 & 0.9 & 410 \\
\hline $1991-92$ & 5.60 & 3.57 & 739 \\
\hline $2012-13$ & 3.76 & 2.34 & 631 \\
\hline $2013-14$ & 3.20 & 2.00 & 558 \\
\hline $1988-89$ & 4.27 & 3.97 & $* 928$ \\
\hline
\end{tabular}

* indicates peak productivity year

Table 1: Area, production and productivity of Blackgram in A.P.
Disease not only in India but also in Pakistan, Bangladesh, Srilanka and adjacent area of south East Asia [2,3].

YMV was first reported in 1960. During 1970's YMV has emerged as serious problem on Blackgram in India in northern plains [4-6]. The infected plants show alternating green and yellow patches on leaves. Leaf size is generally not affected but some time the green area are slightly raised and the leaves shown slightly puckering and reduction in size. The leaves become papery white and thin. The disease is transmitted through white by Bemisia tabaci [7].

Use of disease resistant crop varieties is regarded as an economical and durable method of controlling viral diseases. Identifying source of resistance to YMV on blackgram is a priority area towards research efforts screening blackgram germplasm against YMV for the Identification of resistance source under natural environmental conditions and a number of resistant genotypes have been reported by workers [8-10]. 49 genotypes of blackgram germplasm collected from diverse geographic region were collected and evaluated for resistance under natural environmental conditions in Rabi 2014-2015.

\section{Materials and Methods}

The study was carried out at disease screening field established at R\&D farm, NRI Agritech; and Acharya Nagarjuna University, Nagarjunanagar, Guntur district of A.P., India during Rabi; 2015. Resistance screening was conducted in the natural epidemic conditions using alternative rows of highly susceptible varieties. About 49 varieties were evaluated at R\&D Farm; NRI Agritech Guntur. The disease was scored on a 1-9 arbitrary scale [8].

\section{Rating scale for yellow mosaic virus disease (1-9 scale) \\ -No visible symptoms on leaves or minute yellow specks on leaves. \\ -Small yellow with restricted spread covering 0.1 to $5 \%$ leaf area.}

*Corresponding author: Sambasiva Rao KRS, Department of Biotechnology, Acharya Nagarjuna University, Guntur - 522510, AP, India, Tel: 918632346355; Fax: 918632293378; E-mail: krssrao@yahoo.com

Received June 21, 2016; Accepted August 01, 2016; Published August 03, 2016

Citation: Gopi P, Satyanarayana A, Krishna AR, Rao KRSS (2016) Evaluation of Blackgram Germplasm for Resistance against YMV. J Plant Pathol Microbiol 7: 368. doi: 10.4172/2157-7471.1000368

Copyright: ( 2016 Gopi P, et al. This is an open-access article distributed under the terms of the Creative Commons Attribution License, which permits unrestricted use, distribution, and reproduction in any medium, provided the original author and source are credited. 


\begin{tabular}{|c|c|}
\hline Rating & Reaction \\
\hline 1.0 to 2.0 & Resistant (R) \\
\hline 2.1 to 4 & Moderately Resistant (MR) \\
\hline 4.1 to 5 & Moderately susceptible (MS) \\
\hline 5.1 to 7 & Susceptible (S) \\
\hline 7.1 to 9 & Highly Susceptible (HS) \\
\hline
\end{tabular}

Table 2: Categories are used in assessing the resistant reaction for yellow mosaic virus disease.

\begin{tabular}{|c|c|c|}
\hline S.no & Entry/variety & Disease scoring scale (1-9scale) \\
\hline 1 & PU -19 & 4 \\
\hline 2 & NARENDRA -1 & 8 \\
\hline 3 & TVM -1 & 8 \\
\hline 4 & BARCHART -1 & 6 \\
\hline 5 & PU -13 & 3 \\
\hline 6 & $P U-10$ & 4 \\
\hline 7 & ADT -5 & 9 \\
\hline 8 & KU -301 & 8 \\
\hline 9 & MARCH -404 & 6 \\
\hline 10 & LBG -623 & 9 \\
\hline 11 & $\mathrm{CO}-5$ & 8 \\
\hline 12 & $\mathrm{~T}-91$ & 4 \\
\hline 13 & $\mathrm{~T}-9$ & 4 \\
\hline 14 & TAU -1 & 7 \\
\hline 15 & NRI,LBG -20 & 3 \\
\hline 16 & TU -9814 & 8 \\
\hline 17 & TU -651 & 8 \\
\hline 18 & TU -3113 & 8 \\
\hline 19 & IU -98843 & 9 \\
\hline 20 & IU -652 & 9 \\
\hline 21 & TAU -1-1 & 8 \\
\hline 22 & IU -92-3 & 8 \\
\hline 23 & TPU -4 & 8 \\
\hline 24 & TPU -4-1 & 7 \\
\hline 25 & TU -9814 & 8 \\
\hline 26 & IU 86 & 8 \\
\hline 27 & IU 835 & 9 \\
\hline 28 & IU -67219 & 8 \\
\hline 29 & IU -834 & 9 \\
\hline 30 & IU -861 & 9 \\
\hline 31 & IU -943 & 9 \\
\hline 32 & IU -8810 & 8 \\
\hline 33 & PDU -1 & 8 \\
\hline 34 & TAU -2 & 8 \\
\hline 35 & $\mathrm{PU}-17$ & 8 \\
\hline 36 & PU -30 & 3 \\
\hline 37 & PU -35 & 1 \\
\hline 38 & TU 942 & 8 \\
\hline 39 & JU -3 & 5 \\
\hline 40 & $P U-31$ & 1 \\
\hline 41 & LBG -752 & 9 \\
\hline 42 & LBG -685 & 9 \\
\hline 43 & LBG -402 & 9 \\
\hline 44 & LBG -645 & 9 \\
\hline 45 & LBG -17 & 9 \\
\hline 46 & LBG -22 & 9 \\
\hline 47 & LBG-787 & 8 \\
\hline 48 & JU-2 & 8 \\
\hline 49 & LBG-754 & 8 \\
\hline
\end{tabular}

Table 3: Screening of blackgram genotypes against YMV during Rabi, 2015.

\begin{tabular}{|c|c|c|}
\hline Rating & Reaction & Genotypes \\
\hline 1.0 to 2 & Resistant (R) & PU-31, PU-35. \\
\hline 2.1 to 4 & $\begin{array}{c}\text { Moderately } \\
\text { Resistant (MR) }\end{array}$ & PU-13, PU-10, T-9,T-91 NRILBG-20,PU-30 \\
\hline 4.1 to 5 & $\begin{array}{c}\text { Moderately } \\
\text { Susceptible (MR) }\end{array}$ & PU-19,Barch chart-1,JU-3 \\
\hline 5.1 to 7 & Susceptible (S) & March-404,TAU-1 \\
\hline 7.1 to 9 & $\begin{array}{c}\text { Highly } \\
\text { Susceptible (HS) }\end{array}$ & $\begin{array}{c}\text { TMV-1,ADT-5,KU-301,LBG-623,CO-5,TU- } \\
\text { 9814,Narendra-1,TU-651, TU-3113,IU-98843,IU } \\
\text { 652,TAU-1-1,IU-92-3,TPU-4,TPU-4-1,TU-9814,IU- } \\
\text { 86,IU-835,IU-67219,IU-834,IU-861,IU-943,IU- } \\
\text { 8810,PDU-1,TAU-2,PU-17,TU-942,LBG-752,LBG- } \\
\text { 685,LBG-645,LBG-402,LBG-17,LBG-725,LBG- } \\
787, J U-5\end{array}$ \\
\hline
\end{tabular}

Table 4: Grouping of genotypes screened against YMV in blackgram during Rabi, 2015.

-Yellow mottling leaves covering 5.1 to $10 \%$ leaf area.

-Yellow mottling leaves covering 10.1 to $15 \%$ leaf area.

-Yellow mottling leaves covering 15.1 to $30 \%$ leaf area.

- Yellow discoloration of 30.1 to $50 \%$ leaf area.

- Pronounced yellow mottling and discoloration of leaves and pods reduction in leaf size and stunting of plant covering 50.1 to $75 \%$ of foliage.

- Severe yellow discoloration of entire leaves covering above 75.1 to $90 \%$ of foliage, stunting of plants and no pod formation.

- Severe yellow discoloration of entire leaves covering above 90.1\% of foliage, stunting of plants and no pod formation.

Observations on the disease incidence were taken on randomly selected five plants of each entry and took mean of each entry to assign the category. The following categories are used in assessing the resistant reaction for yellow mosaic virus disease (Table 2).

\section{Results and Discussion}

A total of 49 genotypes screened against YMV to identify the sources of resistance revealed that 2 entries exhibited resistance(R) reaction with rating of 1.0 to 2.0. Six genotypes feel in the category of moderately resistant (MR) with rating scale of 2.1 to 4.0 , three were moderately susceptible (MS) with rating of 4.1 to 5.0; two genotypes were susceptible (S) with rating of 5.1 to 7 ; and 35 genotypes were highly susceptible (HS) with rating 7.1 to 9. The data in Table 3 presents the actual disease resistance /susceptibility reaction of different blackgram genotypes/entries towards YMV disease. Different blackgram genotypes/entries that fall into each category were grouped in Table 4 .

\section{Conclusion}

Evaluation of germplasm for disease resistance is crucial step in controlling plant diseases through host plant resistance. Genes conferring resistance can be to a certain extant identified through routine screening procedures such as germplasm evaluation. In the case of YMV in blackgram, of 49 genotypes screened, 2 entries have been identified exhibiting promising reaction to YMV resistance. Identification of resistant lines is essential in the ambit of integrated 
Citation: Gopi P, Satyanarayana A, Krishna AR, Rao KRSS (2016) Evaluation of Blackgram Germplasm for Resistance against YMV. J Plant Pathol Microbiol 7: 368. doi: 10.4172/2157-7471.1000368

disease management which is upcoming concept in the field of agriculture. Earlier studies identified controlling the viral disease. Similar type of genotype evaluations were previously documented by several workers [9-13]. Our genotypes LBG-17, LBG-402, LBG645 , LBG 685, are highly susceptible to YMV but agronomical and quality wise were superior. Hence improvement of these varieties for YMV resistance is undertaken by developing DNA markers for YMV resistance, resistance for screening molecular aided selection in blackgram improvement.

\section{References}

1. "Mung bean nature seeds row" USDA National nutrient data base for standard reference. US Department of Agriculture.

2. Bokar AK (1981) Pest and disease problems of black gram in west Malaysia Malaysian Agric Jour 53: 29-33.

3. Malik JA (1991) Breeding for resistance to YMV its vector in Pakistan. Mung bean yellow mosaic disease. Proceedings of an International Work Shop. Bangkak, Thailand pp: 41-53.

4. Balamurugan A Department of pathology, Tamilanadu Agricultural University, Maduri, Tamilanadu, India. (TNAU.ac.in).

5. Murtaza MA, Bhatti MA, Gayyam HA (1983) Susceptibility of blackgram lines to white fly and Yellow mosaic. Pak J entomol 5: 49-56.
6. Gaffor A, Zubir M, lqbal SM (1992) Evaluation of selected germplasm of blackgram. Pak J Botany 24: 112-118.

7. Zubir M, Bashir M (2002) Identification of resistance in urdbean against two different viral diseases. Pak J Botany 34: 49-49.

8. Alice D, Nadarajan N (2007) Screening techniques and assesment methods for disease resistance, Department of Pulses, TNAU.

9. Asthana AN (1998) Pulses crop research in India. Indian Journal of Agricultural Sciences 68: 448-452

10. Basandrai AK, Grtan SL, Dandkalia V (1999) Blackgram (phaseolusmungo) germplasm evaluation against different diseases. Indian Journal of Agricultural Sciences 69: 506-508.

11. Ganapathy T, Kuruppiah R, Gunashakernn K (2003) Idenurlctifying the source of resistance for mungbean yellow mosaic virus (MYMV), urd bean leaf crinkle virus and leaf curl virus disease in urdbean (Vignamungo(L) Hepper). In Annual Meating and Symposium on recent Developments in the diagnosis and management of Plant diseses for Meeting Global Challenges, December 1820.University of agricultural sciences, Dharwad p: 30 .

12. Peerajade DA, Ravikumar RL, Rao MSL (2004) Screening of local mungbean collections for powdery mildew and yellow mosaic virus resistance. Indian Journal of pulse research 17: 190-191.

13. Pathak AK, Jhamaria SL (2004) Evaluation of mungbean (Vignaradiate L.) Varieties to yellow mosaic virus. Journal of mycology and plant pathology 34: 64-65. 